\title{
Pengaruh Perendaman Telur dengan Larutan Hidrogen Peroksida terhadap Penurunan Bobot, Haugh Unit dan Indeks Putih Telur Itik Konsumsi Selama Penyimpanan pada Suhu Ruang
}

\author{
Nilawati Widjaya \\ Jurusan Produksi Ternak, Fakultas Pertanian Universitas Bandung Raya \\ Jl. Banten No. 11, Bandung 40272 \\ Email :widjajanilawati@yahoo.com
}

\begin{abstract}
ABSTRAK
Tujuan penelitian ini adalah untuk mengetahui pengaruh perendaman telur dengan larutan hidrogen peroksida terhadap penurunan bobot, Haugh Unit (HU) dan indeks putih telur itik konsumsi selama penyimpanan pada suhu ruang. Metode penelitian adalah experimen dan rancangan percobaan yang digunakan adalah Rancangan Acak Lengkap (RAL) dengan 4 perlakuan masing-masing perendaman dengan larutan aquades, perendaman dengan larutan hidrogen peroksida 1\%, 2\% dan 3\%, dengan setiap perlakuan diulang 6 kali. Peubah yang diamati adalah penurunan bobot telur, $H U$ dan indeks putih telur itik konsumsi. Data dianalisis dengan sidik ragam dan apabila ada pengaruh perlakuan dilanjutkan dengan Uji Jarak Berganda Duncan. Perendaman dengan larutan hidrogen peroksida berpengaruh terhadap penurunan bobot, $H U$ dan indeks putih telur, dan pada konsentrasi $1 \%$ larutan hidrogen peroksida mampu mempertahankan bobot $H U$ dan indeks putih telur itik selama 35 hari penyimpanan pada suhu ruang.
\end{abstract}

Kata kunci : perendaman, hidrogen peroksida, penurunan bobot, haugh unit, indeks putih telur

\section{Effect of Soaking Eggs with Hydrogen Peroxide on Weight Reduction, Haugh Unit and Albumen Index of Duck Eggs During Storage at Room Temperature}

\begin{abstract}
ABSTARCT
This objective of the research was to know the effect of soaking with hydrogen peroxide on weight reduction, haugh unit and albumen index of duck eggs during storage at room temperature. The research was designed as Completely Randomize Design (CRD) wtih four treatments and six replicates each. The treatments were: soaking with aquades, soaking with 1, 2, and 3\% of hydrogen The data were analyzed by analysis of variance and continued with Duncan Multiple Range Test. The results indicated that soaking with hydrogen peroxyde influended the egg weight, Haugh Unit and albumen index at chamber temperature during the storage. Soaking with 1\% hydrogen peroxide showed the best results compared with the other treatments.
\end{abstract}

Key words: soaking, hydrogen peroxide, weight decrease, haugh unit, albumen index 


\section{PENDAHULUAN}

Telur merupakan salah satu bahan makanan yag bernilai gizi tinggi dan mudah diperoleh dengan harga relatif murah, akan tetapi mempunyai sifat mudah rusak. Penyimpanan telur yang tidak baik akan mempercepat penurunan kualitas. Telur mudah membusuk akibat waktu penyimpanan serta mudah terpengaruh oleh keadaan sekitarnya sehingga mengakibatkan penuruna kualitas yang terus menerus selama penyimpanan. Pada batas waktu tertentu tingkat penurunan ini dapat mencapai nilai kualitas di bawah minimum sehingga telur tersebut tidak layak lagi untuk dimakan.

Kesegaran telur menurun selama penyimpanan, umumnya oleh pelepasan CO2 dari isi telur, penguapan air dan juga masuknya mikroorganisme melalui pori-pori telur. Pelepasan CO2 dari isi telur dan peguapan air menyebabkan penurunan bobt telur. Telur ayam segar tanpa diberi perlakuan pengewetan dapat disimpan selama 18-21 hari, sedangkan pada telur segar itik tanpa biberi perlakuan dapat disimpan sampai 25 hari atau 1,2 kali lebih lama (Soepardi,1981). Turunnya kualitas telur tersebut antara lain dapat diidentifikasikan dari besar rongga udara, indeks putih telur, Indeks Kuning Telur, Haugh Unit dan penurunan bobot telur.

Penurunan kualitas telur dapat dihambat dengan cara pengumpulan telur secepatnya setelah ditelurkan, menjaga kebersihan telir itu sendiri, pemberian perlakuan pada kerabang telur, penyimpanan yang baik dan pemasaran secepatnya. Untuk mempertahankan kualitas telur sebelum dikonsumsi perlu adanya penanganan telur yang baik sehingga dapat memperpanjang masa simpan, salah satunya adalah dengan cara melakukan perendaman telur dengan larutan hidrogen peroksida.

Kerabang telur, terutama telur itik, umumnya banyak terdapat kotoran yang menyebabkan suburnya perkembangan mikroorganisme. Itik termasuk unggas air yang bertelur di sembarang tempat sehingga telurnya relatif mudah tercemari oleh mikroorganisme (Rasyaf,1991). Dengan demikian perendaman telur itik dengan larutan hidrogen peroksida diharapkan menurunkan jumlah mikroorganisme sehingga daya awet telur dapat dipertahankan.

\section{MATERI DAN METODE}

Materi penelitian adalah telur konsumsi itik lokal yang berumur satu hari. Jumlah telur yang digunakan sebanyak 288 butir degan bobot telur berkisar 60-65 gram. Telur tersebut diperoleh dari induk yang berumur 8-12 bulan. Larutan Hidrogen Peroksida dengan konsentrasi 35\%. Sebelum digunakan diencerkan menjadi $1 \%$, $2 \%$ dan $3 \%$. Alat yang digunakan: thermometer, Higrometer, lap, timbanagn analitik Ohaus kapasitas 310 gram, gelas ukur, wadah telur, jangka sorong, alas kaca. Rancangan percobaan yang digunakan adalah Rancangan Acak Lengkap (RAL). dengan 4 parlakuan berdasarkan tingkat konsentrasi larutan peroksida. Masing-masing perlakuan terdiri dari 12 butir telur dan diulang 6 kali. Bila ada pengaruh perlakuan yang berbeda nyata maka dilanjutkan dengan Uji Wilayah Berganda Duncan. Anilisis statistika yang digunakan mengacu kepada Gomez dan Gomez (1995).

\section{HASIL DAN PEMBAHASAN}

Hasil pengamatan mengenai pengaruh perlakuan terhadap penurunan bobot, Haugh Unit dan indeks putih telur itik disajikan pada Tabel 1.

Rata-rata penurunan bobot telur itik selama penyimpanan pada suhu ruang, telur yang direndam dengan aquades lebih tinggi dibanding telur yang mendapat perlakuan perendaman dengan larutan hidrogen peroksida.

Telur itik yang tidak direndam dengan larutan hidrogen peroksida penurunan bobot telurnya lebih besar $(\mathrm{P}<0,05)$ di bandingkan telur yang direndam dengan larutan hidrogen peroksida. Hal ini disebabkan adanya pengaruh dari larutan 
Tabel 1. Rata-rata penurunan bobot telur, Haugh Unit dan indeks putih telur itik selama penyimpanan pada suhu ruang

\begin{tabular}{lcccc}
\hline \multirow{2}{*}{ Peubah } & \multicolumn{4}{c}{ Perendaman } \\
\cline { 2 - 5 } & \multirow{2}{*}{ Aquades } & $\begin{array}{c}\text { Hidrogen } \\
\text { Peroksida 1\% }\end{array}$ & $\begin{array}{c}\text { Hidrogen } \\
\text { Peroksida 2\% }\end{array}$ & $\begin{array}{c}\text { Hidrogen } \\
\text { Peroksida 3\% }\end{array}$ \\
\hline Penurunan bobot telur (\%) & $1,93^{\mathrm{a}}$ & $1,14^{\mathrm{b}}$ & $1,11^{\mathrm{b}}$ & $1,07^{\mathrm{b}}$ \\
Haugh Unit & $74,10^{\mathrm{a}}$ & $78,24^{\mathrm{b}}$ & $78,31^{\mathrm{b}}$ & $79,18^{\mathrm{b}}$ \\
Indeks putih telur & $0,08^{\mathrm{a}}$ & $0,09^{\mathrm{b}}$ & $0,09^{\mathrm{b}}$ & $0,09^{\mathrm{b}}$ \\
\hline
\end{tabular}

hidrogen peroksida yang bersifat desinfektan sehingga mengurangi jumlah mikroorganisme yang terdapat pada kerabang telur itik. Dengan berkurangnya jumlah mikroorganisme pada kerabang maka peluang masuknya mikroorganisme ke dalam telur berkurang pula sehingga perombakan isi telur oleh mikroorganisme dapat dihambat dan penguapan air serta gas dapat berkurang. Perombakan alami isi telur berlangsung secara enzimatis terjadi secara lambat dan akan diikuti dengan perubahan yang cepat apabila ditambah dengan aktifitas mikroorganisme (Romanoff dan Romanoff, 1963). Menurut Buckle (1985) selama penyimpanan terjadi penguapan isi telur dan pelepasan gas dari dalam telur telur yang dapat mengakibatkan penurunan bobot telur dan panambahan rongga udara.

Telur yang direndam dengan larutan hidrogen peroksida dengan tingkat konsentrasi yang berbeda masing-masing tidak menunjukkan pengaruh yang nyata. Hal ini sesuai dengan pendapat Djuarni (1983) bahwa penggunaan larutan hidrogen peroksida dengan perbedaan konsentrasi yang sedikit menimbulkan pengaruh tidak berbeda nyata, karena larutan hidrogen peroksida oleh udara segera terurai menghasilkan oksigen yang dapat membunuh mikroorganisme.

Telur yang tidak direndam dengan larutan hidrogen peroksida penurunan Haugh Unit lebih besar $(\mathrm{P}<0,05)$ dibandingkan dengan telur yang direndam dengan larutan hidrogen peroksida. Demikian juga telur yang tidak direndam dengan larutan hidrogen peroksida mengalami penurunan indeks putih telur lebih besar $(\mathrm{P}<0,05)$ dibandingkan dengan telur yang direndam dengan larutan hidrogen paroksida. Hal ini disebabkan adanya pengaruh dari larutan hidrogen peroksida yang bersifat desinfektan sehingga mengurangi jumlah mikroorganisme yang terdapat pada kerabang telur dan mikroorganisme yang masuk ke dalam telur berkurang pula. Dengan berkurangnya jumlah mikroorganisme maka perombakan isi telur berlangsung secara lambat dan pelepasan air serta $\mathrm{CO}_{2}$ dapat dihambat sehingga Haugh Unit telur dapat dipertahankan. Hal ini sejalan dengan pendapat Romanoff dan Romanoff (1963) bahwa penurunrn Haugh Unit disebabkan oleh pelepasan $\mathrm{CO}_{2}$ dari isi telur yang mengakibatkan pecahnya ovomucin sehingga telur menjadi encer. Menurut Romanoff dan Romanoff (1963) penurunan indeks putih telur disebabkan terjadinya penguapan air dan gas $\mathrm{CO} 2$ dari isi telur sehingga sifat basa dari putih telur naik yang pada akhirnya menyebabkan serabut-serabut ovomucin memjadi rusak dan pecah.

\section{KESIMPULAN}

Perendaman dengan larutan Hidrogen Peroksida berpengaruh terhadap bobot, indeks putih telur dan haugh unit telur itik. Pada konsentrasi 1\% larutan hidrogen peroksida mampu mempertahankan penurunan bobot, indeks putih telur dan haugh unit telur itik selama 35 hari penyimpanan pada suhu ruang.

\section{DAFTAR PUSTAKA}

Buckle K.A, RA Edward, GH. Fleet and Wooton, 1985. Food Science diterjemahkan 
oleh Hari Purnomo dan Adiono. Universitas Indonesia Press. Jakarta.

Djuarni, N. 1983. Pengaruh Pencucian dengan Berbagai Tingkat Konsentrasi Peroksida terhadap Daya Awet dan Kualitas Telur Ayam Ras pada Penyimpanan Temperatur Kamar. Fakultas Peternakan. Universitas Padjadjaran. Bandung

Gomez. K.A. dan Gomez. A.A. 1995. Prosedur Statistik untuk Penelitian Pertanian. Diterjemahkan oleh Endang S. dan Justika S. Unversitas Indonesia Press. Jakarta.
Merchant, I. A. 1961. Veterinary Bacteriology and Virology. Jawa State. University Press. Ams Iowa. Pp. 126-127

Rasyaf, M. 1991. Pengelolaan Produksi Telur. Kanisius. Yogyakarta.

Romanoff AL and AJ Romanoff. 1963. The Avian Egg. Jhon Willey and Sons Inc. New York. Pp. 123-867.

Soepardi, 1981. Proses Pengawetan Telur Ayam Konsumsi. Majalah Poultry Indonesia Tahun 1981, hal 15. 